University of Nebraska - Lincoln

DigitalCommons@University of Nebraska - Lincoln

Papers in the Earth and Atmospheric Sciences

Earth and Atmospheric Sciences, Department

$11-2007$

\title{
Sedimentology of the Whiteclay Gravel Beds (Ogallala Group) in northwestern Nebraska, USA: Structurally controlled drainage promoted by Early Miocene uplift of the Black Hills Dome
}

\author{
Christopher R. Fielding \\ University of Nebraska-Lincoln, cfielding2@unl.edu \\ Hannan E. LaGarry \\ University of Nebraska-Lincoln \\ Leigh Anne LaGarry \\ University of Nebraska-Lincoln \\ Bruce E. Bailey \\ University of Nebraska State Museum \\ James B. Swinehart \\ University of Nebraska-Lincoln, jswinehart1@unl.edu \\ Follow this and additional works at: https://digitalcommons.unl.edu/geosciencefacpub \\ Part of the Earth Sciences Commons
}

Fielding, Christopher R.; LaGarry, Hannan E.; LaGarry, Leigh Anne; Bailey, Bruce E.; and Swinehart, James B., "Sedimentology of the Whiteclay Gravel Beds (Ogallala Group) in northwestern Nebraska, USA: Structurally controlled drainage promoted by Early Miocene uplift of the Black Hills Dome" (2007). Papers in the Earth and Atmospheric Sciences. 268.

https://digitalcommons.unl.edu/geosciencefacpub/268

This Article is brought to you for free and open access by the Earth and Atmospheric Sciences, Department of at DigitalCommons@University of Nebraska - Lincoln. It has been accepted for inclusion in Papers in the Earth and Atmospheric Sciences by an authorized administrator of DigitalCommons@University of Nebraska - Lincoln. 
Published in Sedimentary Geology 202:1-2 (November 15, 2007), pp. 58-71 (Selected papers presented at the Eighth International Conference on Fluvial Sedimentology); doi:10.1016/j.sedgeo.2006.12.009 Copyright (C 2007 Elsevier B.V. Used by permission. http://www.sciencedirect.com/science/journal/00370738

Published online December 30, 2006.

\title{
Sedimentology of the Whiteclay Gravel Beds (Ogallala Group) in northwestern Nebraska, USA: Structurally controlled drainage promoted by Early Miocene uplift of the Black Hills Dome
}

\author{
Christopher R. Fielding, ${ }^{1}$ Hannan E. LaGarry, ${ }^{2}$ Leigh Anne LaGarry, ${ }^{2}$ \\ Bruce E. Bailey, ${ }^{3}$ and James B. Swinehart ${ }^{2}$
}

\begin{abstract}
1. Department of Geosciences, 214 Bessey Hall, University of Nebraska-Lincoln, Lincoln NE 68588-0340, USA
2. Conservation \& Survey Division, School of Natural Resources, 113 Nebraska Hall, University of Nebraska-Lincoln, Lincoln NE 68588-0517, USA

3. University of Nebraska State Museum, 307 Morrill Hall, University of Nebraska-Lincoln, Lincoln NE 68588-0338, USA
\end{abstract}

Corresponding author - C. R. Fielding, email cfielding2@unl.edu

\begin{abstract}
The newly recognized Whiteclay Gravel Beds (WGB) of the Miocene Ogallala Group crop out as a narrow, discontinuous ribbon of sands and gravels in Dawes and Sheridan Counties, northwestern Nebraska, USA. The WGB are exposed in a series of municipal gravel quarries and natural exposures that define a linear trench in underlying strata at least $20 \mathrm{~m}$ deep and up to $300 \mathrm{~m}$ wide, with short, southeast-trending reaches separating generally longer east-trending sections. This gravel-filled trench can be recognized from the Nebraska-South Dakota border near Whiteclay, Nebraska southeastward to east of Gordon, Nebraska, a distance of $\sim 30 \mathrm{~km}$. The outcrop belt of the WGB is coincident in location and trend with the Whiteclay Fault Zone. Where exposed in quarries, the walls of the trench are steepsided, vertical, or locally overhanging. Polished surfaces, slickensides, and parallel joint sets are common in the walls of the trench near Whiteclay, but uncommon in those to the east. The narrow belt defined by this trench is filled by stratified gravel $(<2.0 \mathrm{~m}$, typically $<0.3 \mathrm{~m})$ of sedimentary lithologies derived from various Cenozoic units (but principally Anderson Ranch Formation), and sand. Relatively small amounts of unrounded granitic, volcanic, and quartz gravel are preserved in places. Cross-bedding and clast imbrication indicate paleoflow towards the east.

The WGB are interpreted to have formed in response to tectonic upheaval associated with uplift of the Black Hills of South Dakota in Early Miocene times. Fault rupture topography facilitated formation of a steep-sided canyon, or valley, up to $20 \mathrm{~m}$ deep, being virtually straight with sharp bends at intervals of several $\mathrm{km}$. An alluvial channel belt developed in the floor of the valley, filling the available accommodation space with coarse sand and gravel via aggradational stacking of the deposits of successive channels and channel belts. Channel belts were probably braided, with individual channels up to $4 \mathrm{~m}$ deep and a few tens of meters wide. The multi-storey character of the deposit indicates multiple episodes of cutting and filling. The coarse grain-size of the fill suggests energetic discharge with frequent bankfull flows, even though the system had a relatively low gradient (0.004). An abundance of reworked fossil debris is derived from several stratigraphic units, clasts of which have been identified in the fill. The presence of a contemporary merychippine horse and a primitive species of the oreodont Brachycrus constrain formation of the WGB to a short interval within the Early Miocene (c. $17.5 \mathrm{Ma}$ ). The mammal fauna suggests that this stream was a valuable source of
\end{abstract}


water, while fragments of aquatic organisms such as turtles and fish indicate perennial discharge. The WGB provides a crucial window into a pluvial period in the Miocene that is largely unpreserved elsewhere in the basin, facilitated in part by fault rupture topography.

Keywords: Nebraska, Cenozoic, structurally controlled drainage, fluvial system, incised valley fill

\section{Introduction}

Continental stratigraphy is typically fragmentary, with generally only a small fraction of elapsed time recorded in preserved deposits, and more time being lost in omission surfaces of varying magnitude. Accordingly, the reconstruction of paleoclimate and other paleoenvironmental conditions from such archives is challenging, and often time-space frameworks contain large gaps in knowledge due to lack of record. Recognition of discrete stratigraphic "windows" can help to fill in these gaps in knowledge in certain circumstances. This paper describes and interprets one such serendipitous find in the Miocene continental record of the High Plains in northwest Nebraska, USA. It allows new insight into a discrete period of the Early Miocene that is otherwise unrecorded in the region, and which is in many ways out of context. This deposit is, furthermore, a well-exposed and quite unequivocal example of structurally-controlled drainage, allowing new insights into the characteristics of such fluvial milieux.

\section{Regional geological setting}

Regional uplift of the Rocky Mountains and Great Plains region and overfilling of the foreland basin during the Laramide Orogeny forced the retreat of the Cretaceous Interior Seaway (60-65 Ma), resulting in the subaerial exposure and weathering of rock units of Early Cretaceous to Eocene age across the northern Great Plains (e.g., Heller et al., 1988). In northwestern Nebraska (Figure 1), Tertiary strata rest unconformably on pedogenically-modified Cretaceous Pierre Shale (Retallack, 1983; Terry, 1998). The Hartville, Laramie, and Black Hills uplifts provided sediment for rivers which flowed eastsoutheast across the region (Clark, 1975; Stanley and Benson, 1979; Swinehart et al., 1985). Uplift of the Black Hills is generally believed to have ended in the Eocene prior to deposition of the White River Group (Lisenbee and DeWitt, 1993).

Overlying the Pierre Shale (Late Cretaceous) are, in ascending order, the volcaniclastic claystones and siltstones of the White River Group (late Eocene-Oligo- cene), the volcaniclastic sandstones of the Arikaree Group (late Oligocene-Early Miocene), and the terrigenous clastic deposits of the Ogallala Group (Miocene). These strata are some of the most highly fossiliferous rocks exposed in North America (Figure 2). All of these units contain incised fluvial systems (paleovalley fills) that drained broadly away from the orogenic mountain range eastward across the overfilled foreland (Swinehart et al., 1985).

The Ogallala Group (Figure 2) consists principally of mudrocks and sandstones representing several distinct episodes of aeolian and fluvial sedimentation generally resulting from the uplift of the Rocky Mountains to the west. Carbonate nodules formed in paleo-phreatic zone environments, and paleosols are common, as are root traces and vertebrate fossils. A variety of Formation and Member level units has been defined within the Ogallala Group (Figure 2), with the newly-defined Whiteclay Gravel Beds an as yet unassigned unit near the base. The unit maps as a discrete, eastsoutheast-trending, linear belt of coarse-grained clastic sediment that appears to be discordant to both interpreted Cenozoic drainage axes in the region (Swinehart et al., 1985) and modern fluvial drainage patterns (Figure 1). The trend and location of the outcrop belt, however, are closely coincident with the surface trace of the Whiteclay Fault Zone, which is estimated to displace Cenozoic stratigraphic units by up to $70-100 \mathrm{~m}$ in the study area (Souders, 1981).

The Whiteclay Gravel Beds have been exposed at the surface 1) by natural landscape processes, which have formed inverse topography in many areas in which the gravel-rich alluvial facies form linear topographic highs (Figure 3A), and 2) by commercial and municipal excavations for road base materials (Figure 3B).

\section{Sedimentology of the Whiteclay Gravel Beds (WGB)}

\subsection{Methods}

The WGB were mapped by a combination of ground investigation and examination of remotely-sensed data. Gravel excavations and natural exposures were vis- 


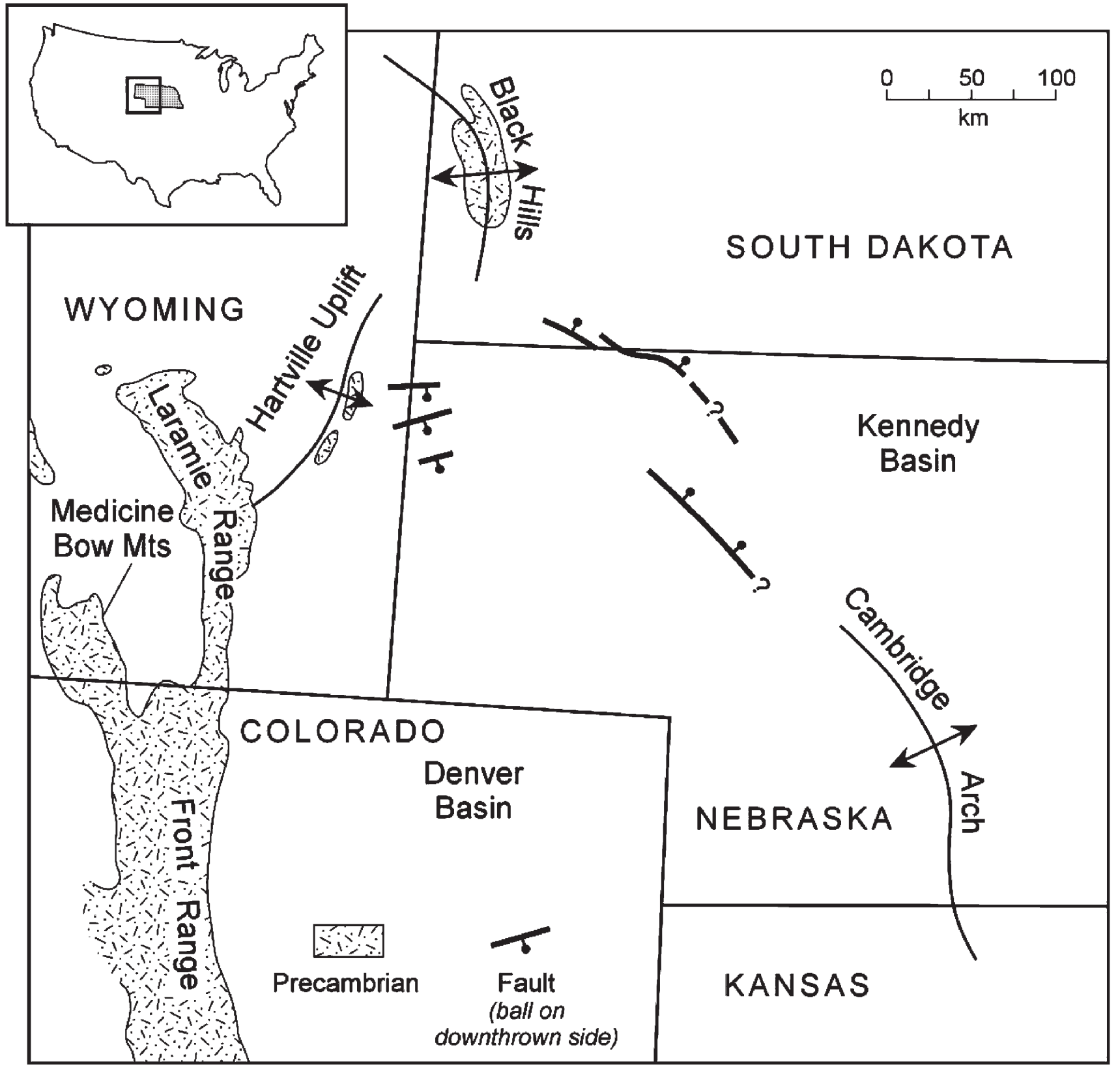

Figure 1. Maps showing the location of the study area in central-northern USA. Note the surface traces of faults propagating outward from the Black Hills Dome. The study area is the northwestern part of Nebraska.

ited, vertical sections logged, and facies relationships recorded in two and three dimensions using maps and photomosaics. Paleocurrent data were collected from selected sedimentary structures, notably cross-bedding in sands and clast imbrication in gravels. Clast imbrication measurements were restricted mainly to large clasts, and only in situations where the original horizontal surface could be established independently. Maximum clast size was assessed at several localities by measuring the a-axis of the twenty largest visible clasts and calculating the mean of each population.

\subsection{External geometry of the WGB lithosome}

The WGB are preserved as a linear, broadly westnorthwest-eastsoutheast-trending belt between 100 and $300 \mathrm{~m}$ wide, inset predominantly into the older Miocene Anderson Ranch Formation (Hunt, 2002; Figure 2). The belt has been mapped by tracing strings of natural and artificial exposures across the landscape physically and by means of remote imagery. In this way, a single, linear tract can be traced from the Nebraska/South Dakota State line at Whiteclay, NE, eastsoutheastward to north- 


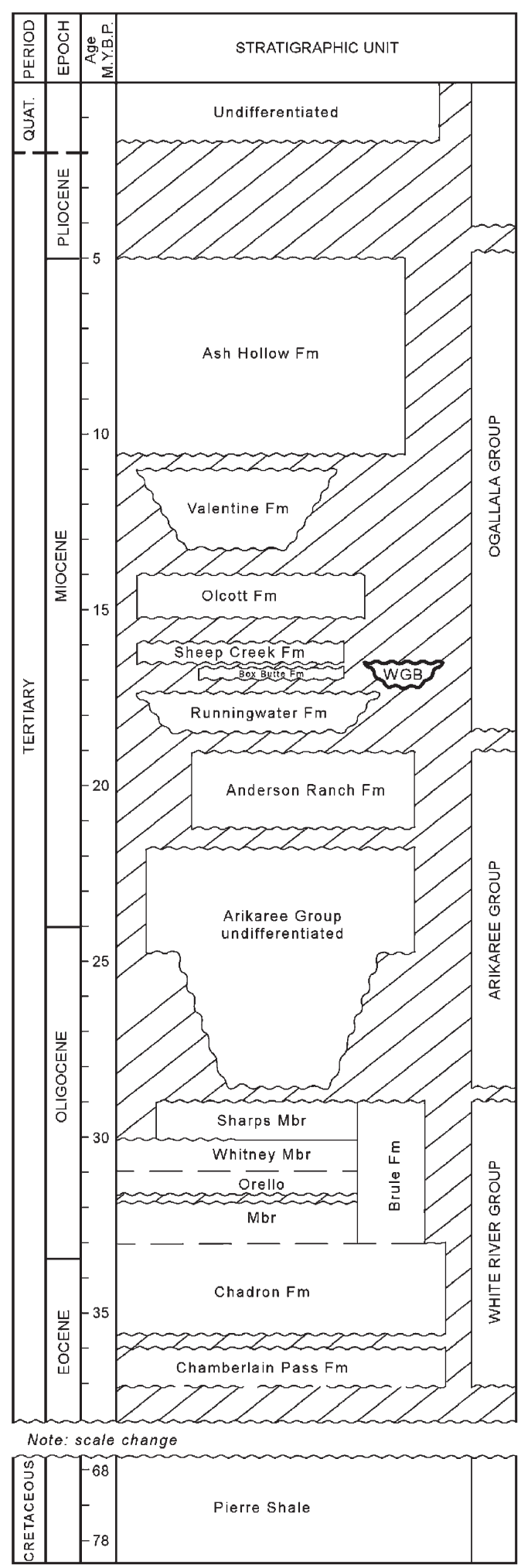

Figure 2. Cenozoic stratigraphic column for northwestern Nebraska (modified from Swinehart et al., 1985).

east of the town of Gordon, NE, a distance of c. $30 \mathrm{~km}$ (Figure 4). Our mapping has established the course of the channel in considerable detail. Many sections of the channel are virtually straight, with apparently abrupt corners forming an en echelon pattern propagating away from the southern Black Hills uplift of South Dakota (Figures 1 \& 4). The channel occupies a position within the surface trace of the Whiteclay Fault Zone 

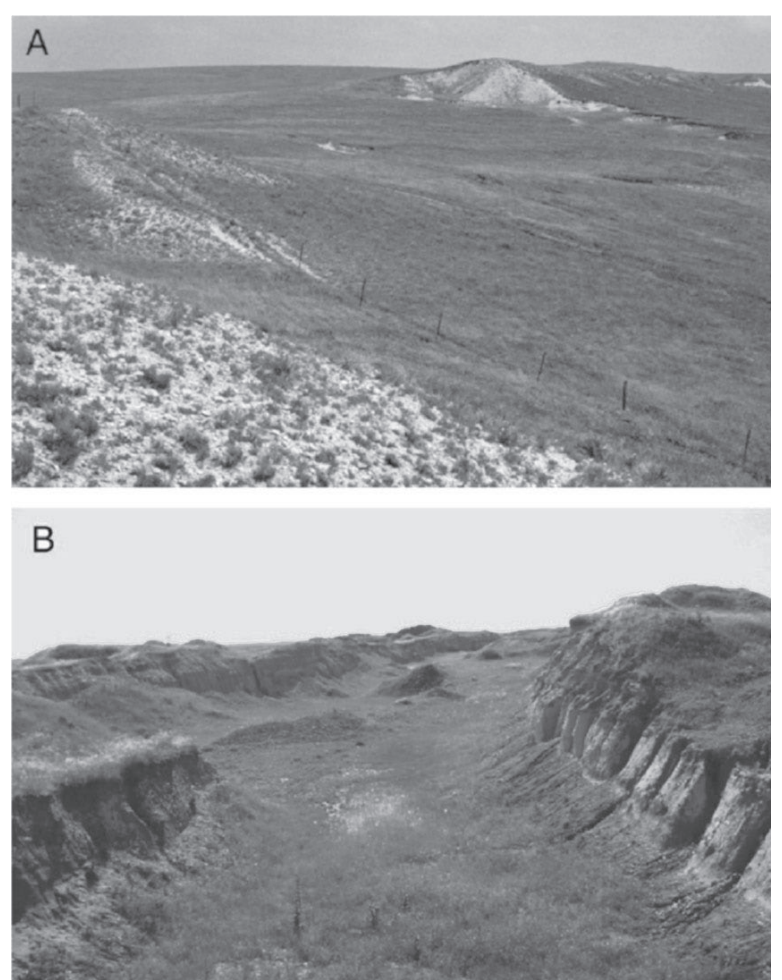

Figure 3. Photographs illustrating principal styles of exposure of the Whiteclay Gravel Beds. A) Natural inverted topography exposure on a ridge top, Collins property. B) Municipal excavation for road base, northeast of Gordon.

near Whiteclay (including the Pine Springs Ranch locality: Figure 4), but some distance to the south of, and parallel to, the fault trace further east (Figure 4).

Since the WGB are preserved at or near the present land surface, it is possible that the original gradient of the formative stream may be preserved. Comparison of surface elevations representing the top of the channel fill at various locations reveals some interesting patterns. At the Pine Springs Ranch locality, close to the westnorthwestern end of the mapped belt, the WGB occur at an anomalously low elevation $(1060 \mathrm{~m})$, whereas the remainder of the major exposures show a progressive decline in elevation from Reeves' Pits (1200 m) eastsoutheast to the Gordon Pits $(1110 \mathrm{~m})$, giving an approximate gradient of 0.004 (Figure 4). The progressive decline in elevation from Reeves' Pits to the Gordon Pits is interpreted as a more or less unmodified fluvial gradient, whereas the anomalously low elevation of the WGB at Pine Springs is interpreted to be the result of post17.5 Ma tectonic activity. Evidence of post-WGB structural activity is preserved in the Pine Springs Pits, in the form of fractured, sheared and slickensided WGB gravels, vertical to locally overturned gravel-basement contacts, and small-scale fault offsets of strata (Figure 5), and the locality lies within the mapped surface trace of the Whiteclay Fault Zone. Furthermore, a tremor of
Richter Magnitude 4.5 near Whiteclay, NE, in May 2003, and other historical events indicate that the Whiteclay Fault Zone is still active in modern times.

At most localities, the margins of the WGB tract are steep-sided, with walls dipping at $60-90^{\circ}$, being locally overturned as noted above (Figure 5). Numerous widespread exposures of the contact confirm that this is an original, unmodified relationship, i.e., that the channel that formed the WGB had precipitous banks, up to $20 \mathrm{~m}$ high. Locally, the channel wall is terraced (Figure 5A), with narrow $(<10 \mathrm{~m})$, flat shelves generally on the upper slope. Where commercial excavations have exposed the floor of the channel, such as at Gordon, it is an irregular, though generally flat-lying surface.

\subsection{Internal facies characteristics}

The WGB comprise a heterogeneous assemblage of generally poorly-consolidated gravels, sandy gravels and sands, with local carbonate-cemented conglomerates and minor, pedogenically-modified silts mainly near the top of the channel fill (Figure 6). Other than in the occurrence of silt at the top of the section, the WGB display no obvious fining-upward trend. The gravel-sized clasts $(<2 \mathrm{~m}$ in long axis diameter) are composed principally of carbonate-cemented siltstone and sandstone eroded from the Cenozoic host rocks (principally Anderson Ranch Formation), younger upper Arikaree Group and basal Ogallala Runningwater Formation (Figure 2; Cook, 1965; Skinner and Johnson, 1984; Bailey, 2001). Locally, granules and pebbles of more exotic, igneous and metamorphic lithologies are found, and sand grade facies comprise a mixture of intrabasinal lithic grains and monomineralic quartz and feldspar. Locally, clasts of cemented gravel were found within the gravels themselves, suggesting some recycling of intraformational debris. A variety of fossil fragments were found within the channel deposits, notably vertebrate teeth, but including jaw and other bone material of a variety of mammals, fish debris, turtle carapace fragments, and petrified wood.

In many places, the contact with the host siltstone and fine grained sandstones is a smooth, polished surface. Elsewhere, angular to rounded blocks and larger enclaves (up to $10 \times 10 \times 2 \mathrm{~m}$, at Pine Springs: Figure 7) of the host material were found near the foot of the channel wall, encased or surrounded by channel fill gravels and sands.

\subsubsection{Facies 1 - Crudely stratified and imbricated pebble to boulder gravel}

Facies 1 comprises wedges and sheets of moderately to well-sorted, well-rounded, clast-supported, peb- 


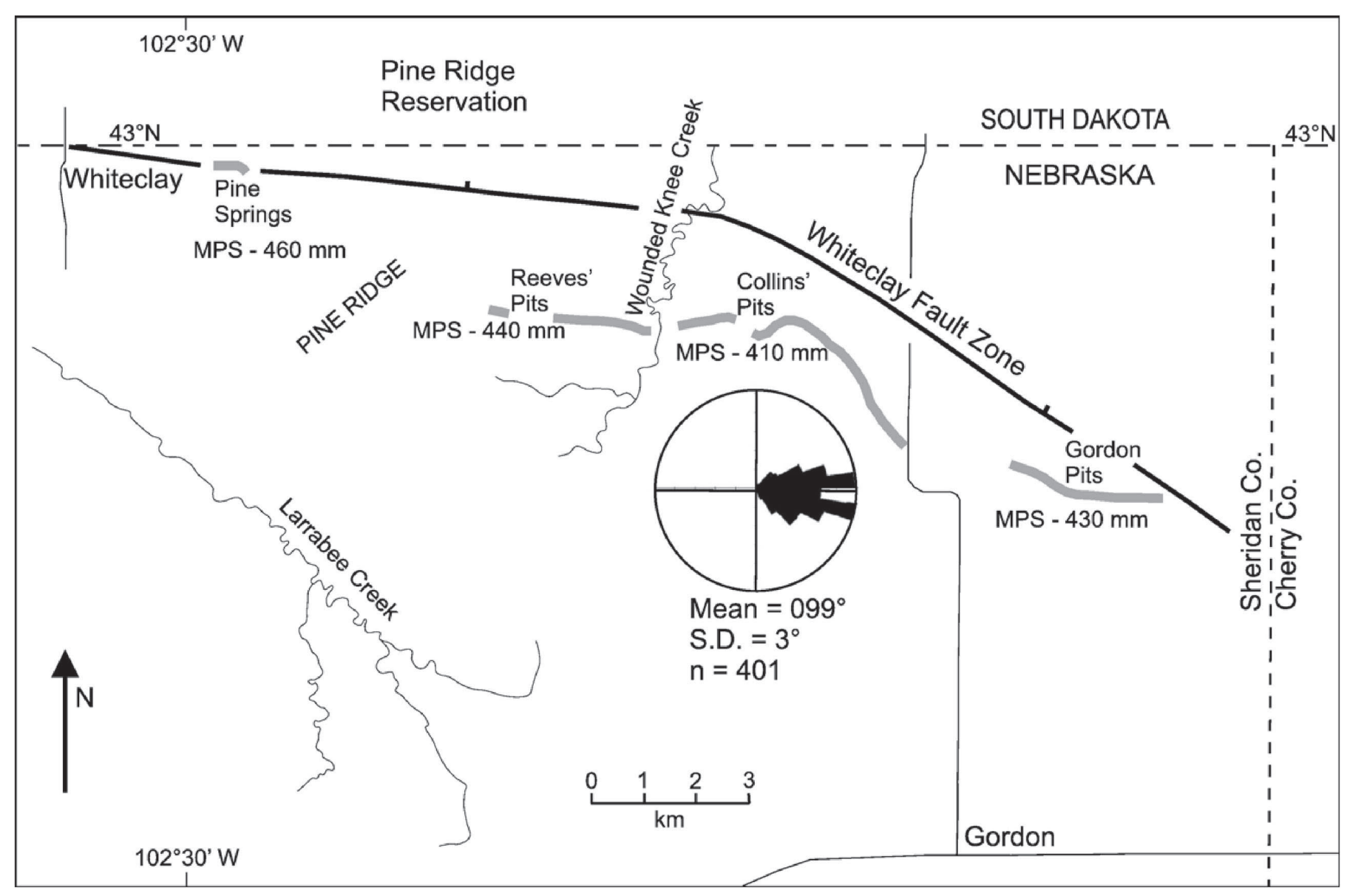

Figure 4. Map showing the mapped course of the Whiteclay Gravel Beds (WGB) fluvial system (grey line) and the surface trace of the Whiteclay Fault Zone (black line, ticks point to downthrown block). Note the generally eastsoutheast trend of the channel belt, with numerous straight reaches terminated by abrupt bends. "MPS" refers to Maximum Particle Size data, calculated for each locality by taking the mean of the 20 largest visible clasts. Circular histogram shows all paleocurrent data collected from the WGB in this study.

ble to boulder gravels (Figure 6A). Locally, Facies 1 is the dominant constituent, whereas where the lithosome is more heterogeneous, Facies 1 typically occurs at the base of the section (for example, at the Gordon pits: Figure 8). Clasts are mainly oblate to triaxial (bladed) in form with lesser equiaxial and prolate (rod-like) shapes (Zingg, 1935), and are composed of intrabasinal, carbonate-cemented siltstone and sandstone. Gravels are typically clast-supported but most contain a subordinate, well-sorted medium-grained sand matrix. Maximum Particle Size (MPS) was calculated as the mean of the 20 largest clasts visible at a given exposure, and varies from $46 \mathrm{~cm}$ at Pine Springs to $41 \mathrm{~cm}$ at Collins' pits. There appears to be no consistent alongstream trend evident from MPS data (Figure 4).

Facies 1 typically displays little or no apparent stratification, other than crude bedding evident locally from clast long-axis alignment or particle size differentiation (Figure 6A). The most common sedimentary structures are b-axis (and less commonly, a-axis) clast imbrication, particularly of the larger oblate and bladed clasts, and cluster bedform remnants (Brayshaw, 1984) are common around the largest clasts. No systematic or persistent lateral or vertical variations in grain-size were noted within Facies 1. Paleocurrent data derived from imbrication of large clasts indicate a generally east to eastsoutheast paleoflow direction with little dispersion about the mean direction, being typically parallel or sub-parallel to the trend of the adjacent channel margin.

\subsubsection{Facies 2 - Flat-stratified gravel, sandy gravel and in- terstratified sand and gravel sheets}

Facies 2 is locally abundant (for example, in the Pine Springs Pits: Figure 7B) but is generally a subordinate component of the WGB. It comprises sheets of variable texture and fabric, often interstratified with Facies 1 and 3. Gravel in Facies 2 is grossly similar to that in Facies 1, but is typically somewhat finer-grained, bettersorted, and is stratified (Figure 6 and Figure 7). Stratification is typically defined by clast size variations, clast elongation, and by variations in sand content. The principal stratification types preserved are a crude flat or 

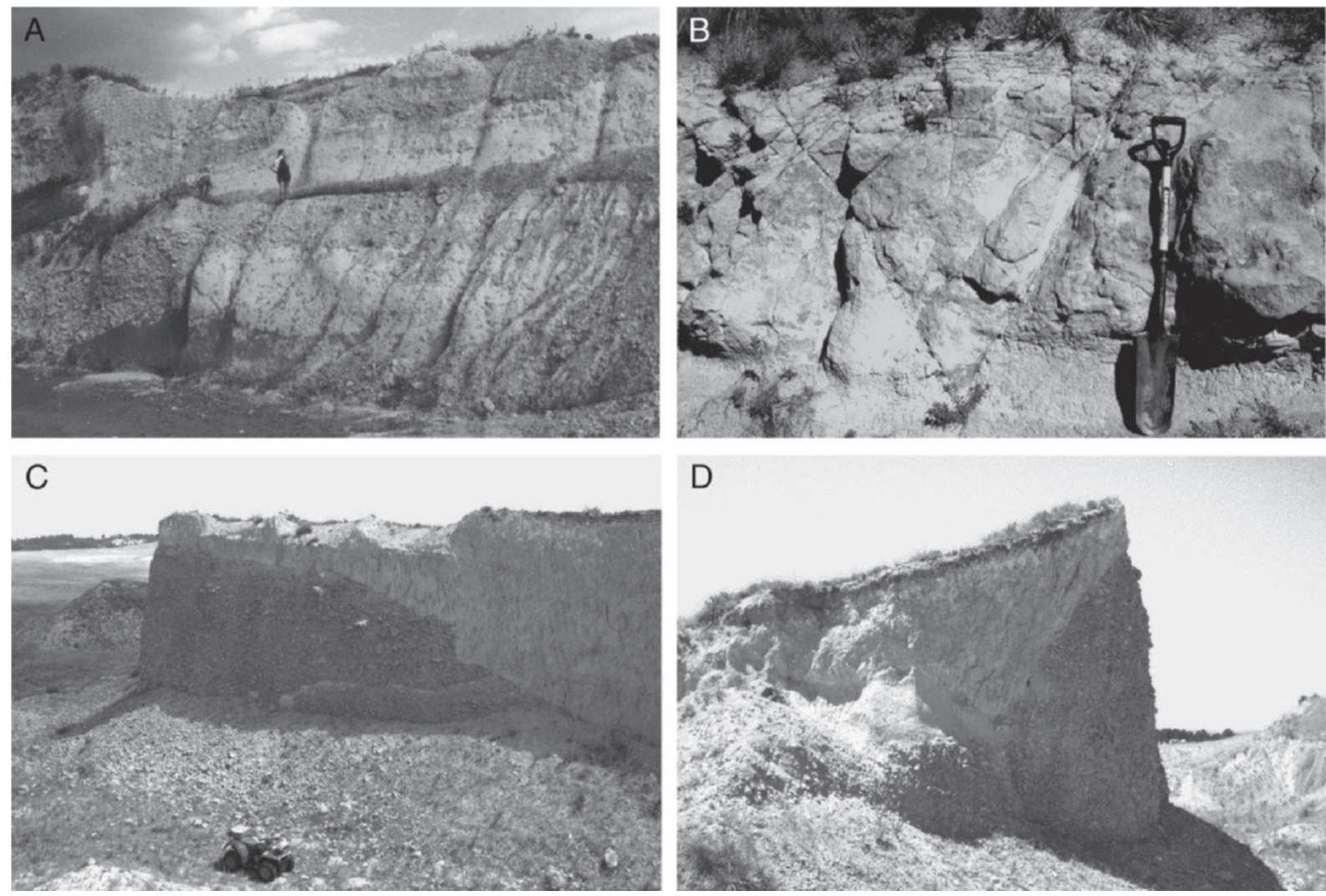

Figure 5. Photos to illustrate channel margin features of the Whiteclay Gravel Beds. A) Exhumed southern wall of the channel belt at the Gordon Pit 1, showing a steep, possibly terraced bank with pods of gravel in contact with the host strata. Geologist for scale $1.8 \mathrm{~m}$. B) Close-up of smallscale fault offsets in the host rock lithology at Pine Springs Ranch quarry, suggesting tectonic activity postdating emplacement of the fluvial gravels. C) View of the southeastern wall of the Pine springs Ranch quarry (Figure 7) facing southeast, showing the precipitous nature of the channel belt wall. Face is c. $10 \mathrm{~m}$ high. D) View of the same corner as is shown at the left end of C), from the opposite direction, showing how the bank of the channel belt has been overturned locally by neotectonic activity.

low-angle planar stratification. Some cluster bedforms were noted, and clast imbrication is evident among the more gravel-rich intervals. Stacks of normally graded beds each c. $0.3 \mathrm{~m}$ thick were noted in this facies at some localities. Furthermore, some zones preserve an openframework gravel fabric. Paleocurrent data indicate similar patterns to those described for Facies 1.

A local variant of Facies 2 comprises poorly sorted fine-to coarse-grained sand with dispersed finer-grained gravel, locally in sufficient concentration to form a clastsupported fabric but more commonly matrix-supported (Figure 6B). Clasts in this variant are mostly small pebble grade, and often angular to subangular rather than the more typical rounded shapes. This sub-facies displays similar flat stratification and cross-stratification to other variants of Facies 2, into which it is in many places laterally and vertically transitional.

\subsubsection{Facies 3 - Cross-stratified, gravel, sandy gravel and interstratified sand and gravel channel fills}

Facies 3 comprises intervals of large-scale trough cross-stratified gravel, sandy gravel and interstratified gravel/sand that appear to define simple channel fills 20-50 $\mathrm{m}$ wide and 2-4 $\mathrm{m}$ deep (e.g., Figures 6 \& 8). Internally, this facies contains trough-form bedding surfaces concordant with the basal erosion surface and scaled with the overall channel form, comprising sets of trough cross-bedding on various scales with some zones of open-framework gravel. Paleocurrent relationships are similar to the other facies.

\subsubsection{Facies 4 - Trough cross-stratified sand}

Facies 4 is overall a subordinate component of the WGB, and is confined to wedges, sheets and channel fills that are typically interstratified with other facies (e.g., Figures 6 \& 8). It comprises well-sorted, browncolored, typically medium-grained sand locally with dispersed small gravel. Trough cross-stratification is ubiquitous with sets ranging from $0.1-0.5 \mathrm{~m}$ in thickness, and flat stratification is also common. Dispersed angular to subrounded, clay and silt clasts (up to $72 \mathrm{~cm}$ ), cemented gravel clasts, and vertebrate bone debris are locally abundant. Paleocurrent data show similar relationships to those derived from Facies 1 and 2. 

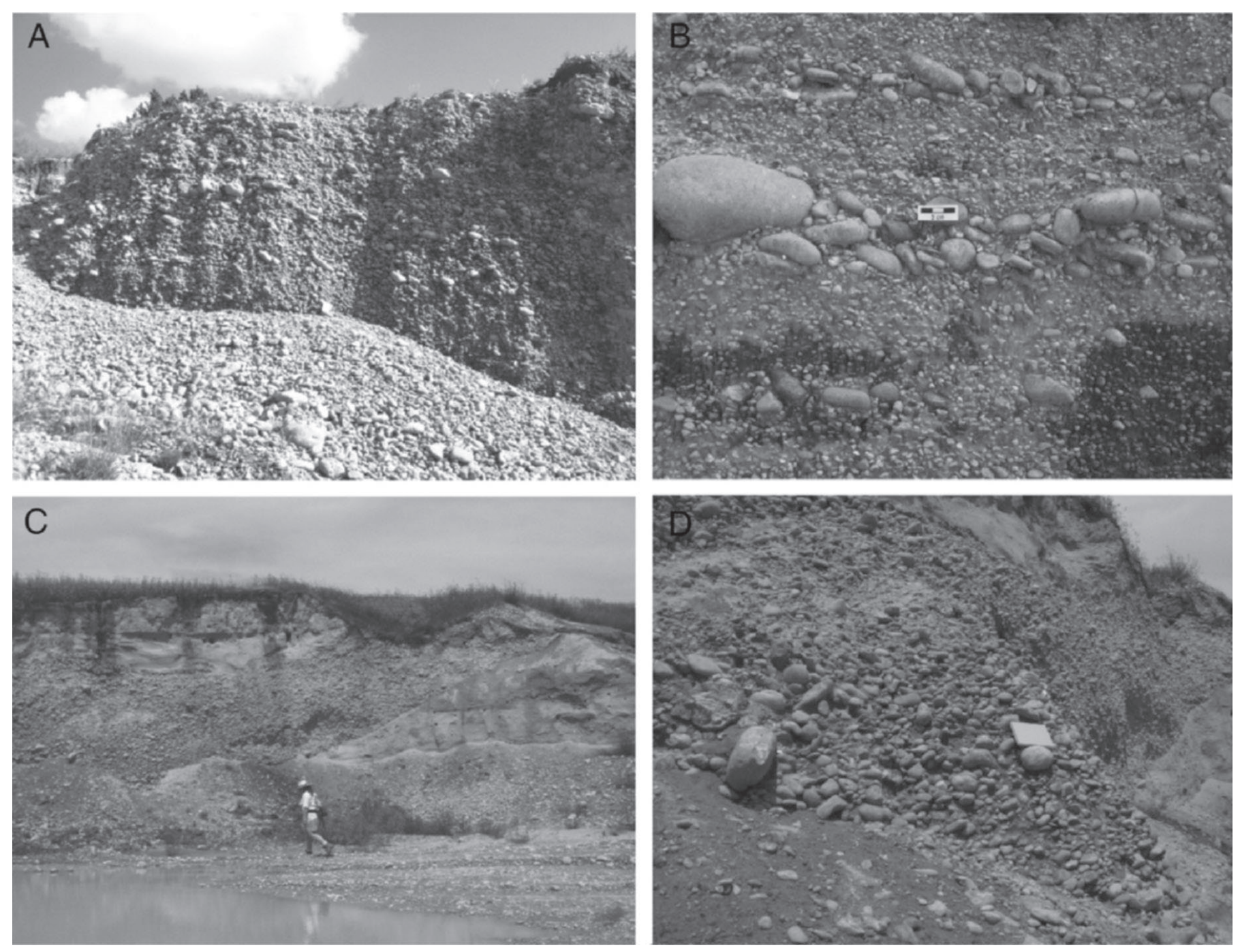

Figure 6. Photos of the principal Whiteclay Gravel Beds lithofacies. A) Facies 1 at Pine springs Ranch quarry, showing crude stratification and local imbrication of large clasts. Cliff is c. $4 \mathrm{~m}$ high. Paleoflow was from right to left. B) Facies 2 at Reeves' property, showing well-developed flat stratification defined by variations in texture and fabric, with imbrication of some larger clasts (paleoflow was from right to left). Note also the abundance of more matrix-rich, small, angular pebble gravel. C) Alternations of Facies 3 (channel-form gravels) and Facies 4 (cross-stratified sands) at Gordon Pit 1. Paleoflow was from left to right. Geologist for scale $1.8 \mathrm{~m}$. D) Close-up of contact visible in centre-left of C), showing deeply scoured base of Facies 3 and imbrication of the larger clasts. Notebook for scale $19 \mathrm{~cm}$. Paleoflow was from left to right.

\subsubsection{Facies 5 - Pedogenically modified silt, and interstrati- fied sand-silt}

Facies 5 is typically found at the top of the channel fill (e.g., Figures $6 \& 8$ ), and comprises one or more interval of silt or interstratified sand-silt with pedogenic fabrics and features (peds, blocky or prismatic structure, rhizotubules, color mottling). Complicating this is the common overprinting by modern soils, with extant plant roots penetrating through the interval where present.

\subsection{Facies Interpretation}

The channel-confined character of the WGB as a whole, the coarse-grained, unbioturbated facies assemblage dominated by unidirectional flow structures, and the abundance of fossil debris of land mammals and aquatic organisms (turtles and fish), together strongly indicate a fluvial environment of deposition. Paleocurrent data indicate an eastward direction of water and sediment dispersal, as do changes in elevation data from the eastern exposures (Figure 4). The strong coincidence in location and trend between the WGB and the Whiteclay Fault Zone suggest a causal relationship, and the trace of the channel course (extensive straight reaches with abrupt bends) indicates a strong structural control on channel geometry and orientation. The low dispersion about the mean for paleocurrent data sets at individual localities suggests that channels were more or less straight, perhaps wandering somewhat between steep-sided canyon walls. Imbrication data, in particular, are generally 
A

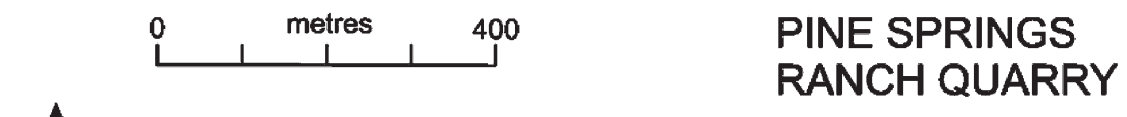

$N \uparrow$
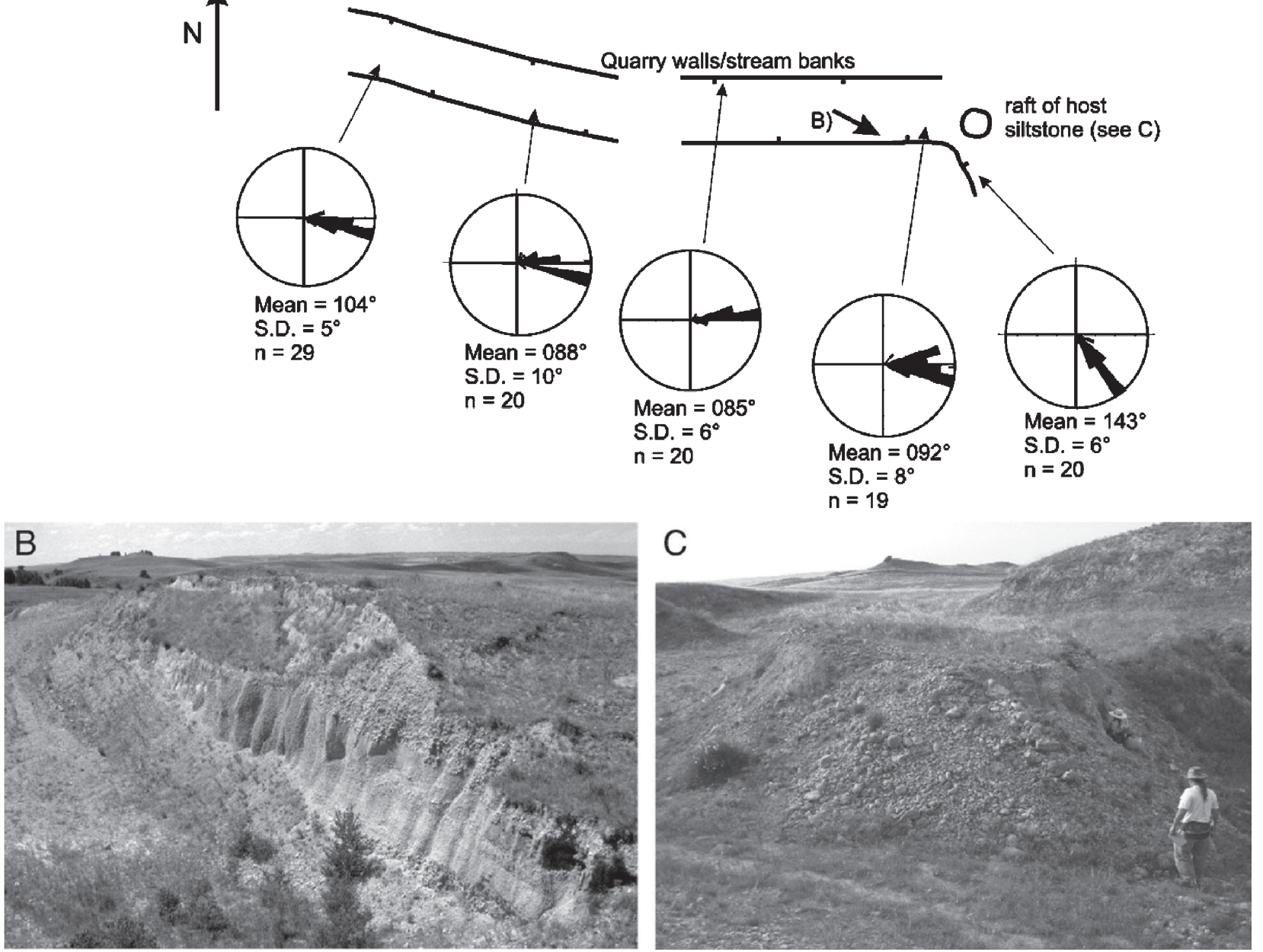

Figure 7. A) Map showing exhumed course of Whiteclay Gravel Beds channel belt at the Pine Springs Ranch quarry. Note the abrupt change in direction at the eastern end of the nearly straight excavation, and the location of a raft of the host lithology in the floor of the quarry that is surrounded on all sides by gravel of the Whiteclay Gravel Beds. This block is interpreted as a raft of the host material that was either derived from bank collapse, or (more likely) undermined from the channel floor. Note also the low dispersion in paleoflow direction indicators, and parallelism with the channel belt walls over the entire extent of the exposure. B) View of the southeastern wall, facing southeast (see A for the location), showing alternation between Facies 1 (crudely stratified, coarse gravels) and Facies 2 (flat-stratified gravels and sandy gravels) in the face, and the precipitous channel belt wall exposed by the excavation. Face is c. $10 \mathrm{~m}$ high. C) Interpreted raft of siltstone believed to have been undermined from the channel floor and entrained within the flow of the formative channel. Geologists for scale $1.8 \mathrm{~m}$.

regarded as reliable indicators of paleoflow direction (Bluck, 1974; Rust, 1975), and in the WGB show very close alignment with local channel bank orientations.

The coarse grain-size and rounding of the channel fill sediments suggest high energy discharge, which would have been constrained by the high, steep banks. The well-developed grain size segregation among Facies 1-3, and the scarcity of mixed-grain-size lithologies (diamicts, matrix-supported gravels) suggests that in general, flows carried relatively low sediment concentrations, and were able to sort effectively the wide range of grain sizes delivered into the Whiteclay river. The matrix-supported variant of Facies 2, on the other hand, seems to indicate that some flows carried higher sediment concentrations that were at times deposited en masse, preventing effective segregation of grainsize populations into well-developed stratification. The abundance of fossil debris of aquatic organisms, the lack of any indicators of semi-arid or arid conditions (pedogenic features such as rhizotubules, calcrete development, strong horizonation, etc.) seems to suggest that the WGB accumulated under conditions of relatively constant water supply.

The majority of coarse debris in the WGB, including all of the coarsest material, is derived from formations exposed in the channel walls, suggesting that much of 


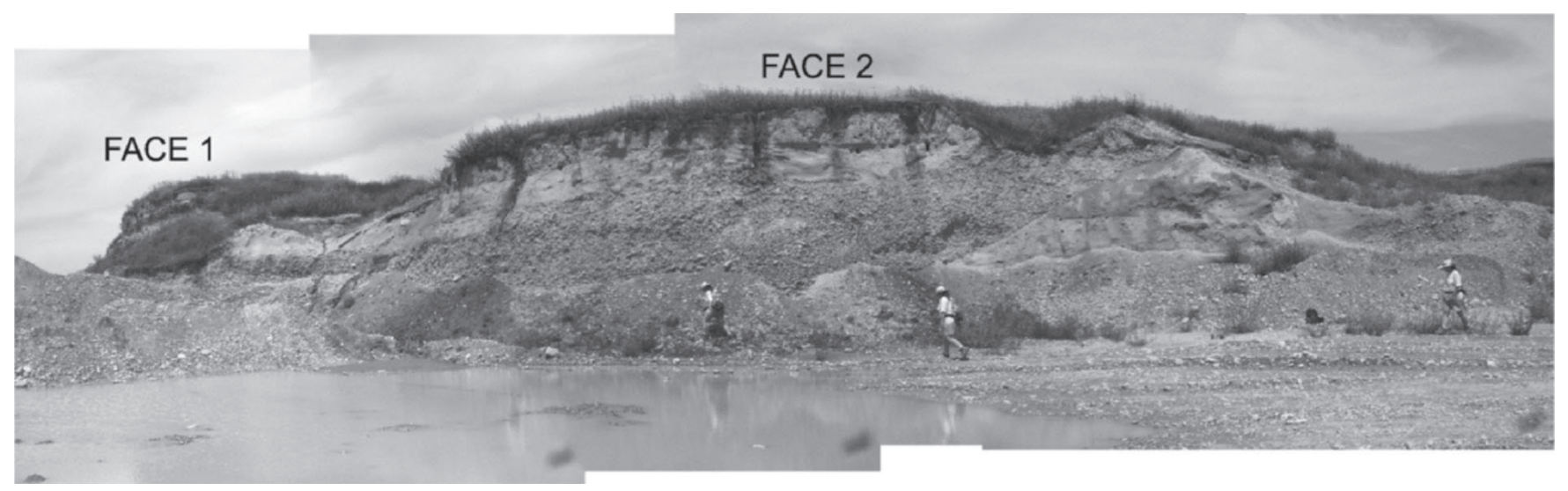

GORDON PIT 1, FACES $1+2$

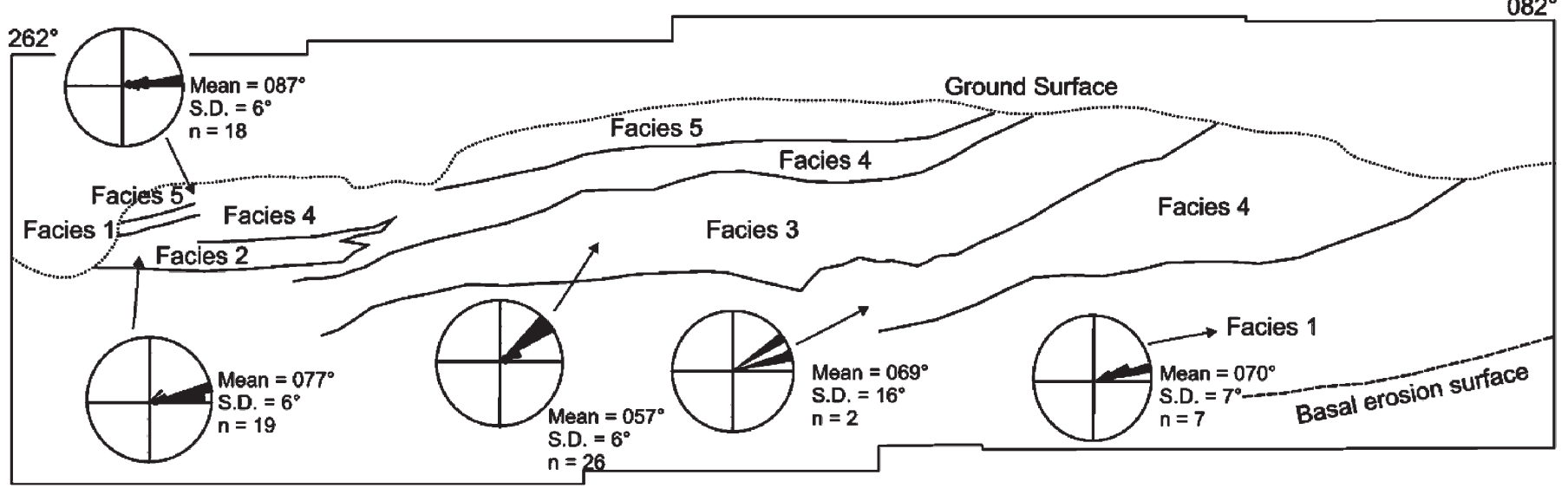

Figure 8. Photomosaic and interpretive line drawing of the northwest face of the Gordon Pit 1, showing facies relationships and paleocurrent data. Note that the left end of the photomosaic shows the exposure at a greater distance, owing to difficulties in acquiring orthogonal images. Paleoflow was from left to right. Geologist for scale (thrice) $1.8 \mathrm{~m}$.

the sediment load carried by formative channels was derived from channel incision, collapse and undermining of channel banks, and from reworking of channel sediments. However, the subordinate component of small gravel derived from crystalline rocks indicates that the stream system was somehow connected to a hinterland of exposed crystalline basement rocks.

The complex internal architecture of the WGB (e.g., Figure 8) indicates that the formative channel was not cut and filled in a single event, but rather was active over a protracted period and filled in a composite fashion. This impression is reinforced by the fact that the WGB lithosome is not a single architectural form (i.e., one $\mathrm{CH}$ element using the terminology of Miall, 1985), but rather is a mosaic of numerous elements, including channels $(\mathrm{CH})$, gravel sheets (GB), sandy bedforms (SB) and minor matrix-supported gravels (SG: all codes from Miall, 1985).

Facies 1 is interpreted as arising principally from the movement of diffuse gravel sheets and low amplitude macroforms along the floor of a low-sinuosity, perhaps braided channel (Smith, 1974; Hein and Walker, 1977; and see review by Bridge, 2003). Facies 2 is interpreted in a similar way, but in cases where the sediment population at a given time and point on the channel contained significant proportions of both gravel and sand. The less well-sorted, angular gravel-rich variant of Facies 2 is interpreted to record periods when the sediment concentration in flows was unusually high, perhaps following a nearby bank collapse or some other abrupt introduction of large volumes of new material. Clast imbrication and cluster bedforms are common features of modern gravelly, low-sinuosity rivers (e.g., Smith, 1974; Rust, 1975; Church and Gilbert, 1975; Lunt et al., 2004). Both Facies 1 and 2 may be remnants of low-amplitude unit bars of various kinds (cf. Smith, 1974; Hein and Walker, 1977; Bluck, 1979), the quality and extent of exposure not being sufficient to allow confident diagnosis of channel/barform relationships (cf. Lunt et al., 2004).

Facies 3 is interpreted as the fills of thalweg channels that were the principal axes of water and sediment transport in the Whiteclay river system. From their di- 
mensions, channels were of the order of 2-4 m deep and 20-50 m wide, and evidently migrated over the limited width of the channel floor environment (100-300 m). The internal architecture of the channels, with concentric bedding surfaces concordant with the basal erosion surface, is similar to the interpreted braided channel confluence pool facies documented from the Rhine Valley Pleistocene gravels by Siegenthaler and Huggenberger (1993), and may be examples of the "nested channel cuts" described from Cretaceous strata by Holbrook (2001). At a smaller scale, the cross-bedding is indicative of sediment movement in channel floor dunes of varying dimensions, and the zones of open-framework gravel may be interpreted as resulting from leeside separation of gravel from sand in the front of some bedforms (cf. Lunt and Bridge, 2005).

The wedges and sheets of well-sorted, mediumgrained sand that comprise Facies 4 are somewhat anomalous in the context of Facies 1-3, but nonetheless are commonly found interfingering with the gravelly channel fills of Facies 3. Given this, they are interpreted as channel fill deposits formed at times of minimal gravel supply, and may reflect times of decreasing water and sediment dispersal through the system. The abundance of mud clasts within the sands indicates that the process of channel widening by bank collapse was still active during these periods, and that such soft clasts were perhaps most likely to be preserved when transported with sand rather than with gravel. Sand moved along the channel floor mainly as small, three-dimensional dunes at these times, possibly in a manner similar to some modern braided streams in the region (e.g., Smith, 1971; Blodgett and Stanley, 1980; Bridge et al., 1986).

Facies 5 (pedogenically modified silts and finegrained sands), where evident, is always at the top of the channel fill and forms a ragged blanket over the coarser-grained facies described above. Accordingly, Facies 5 is interpreted as deposits of shallow, gentle flows during the final filling and abandonment of the WGB river system, and soil formation following abandonment and stabilization of the alluvial surface.

\subsection{Facies architecture}

The available data indicate that the WGB comprise a series of discrete channel fills and other architectural elements of the order of meters thick and up to a few tens of meters wide, contained (or nested) within a largerscale erosion surface that is up to $20 \mathrm{~m}$ deep and up to $300 \mathrm{~m}$ wide. Although the quality and extent of exposure do not allow full disclosure of architectural rela- tionships, the dataset suggests that the WGB lithosome is a small valley fill that is one channel-belt in width and composed of stacked, smaller-scale channel fills. The WGB lithosome satisfies the criteria set out by Fielding and Gibling (2005) and Fielding (in press) for recognition as a valley fill, namely 1 . the master erosion surface is at a scale that is out of context with enclosing fluvial strata, 2 . the master erosion surface can be traced as a discrete entity over a considerable distance, 3 . the depth of incision recorded by the master erosion surface is several times the depth of scour (thickness) recorded by component channel fills, and 4 . the fill enclosed by the master erosion surface comprises numerous smallerscale channel bodies. Regrettably, the nature of the exposure does not allow the delineation of bounding surface relationships at the level of detail necessary to further evaluate architectural relationships (cf. Holbrook, 2001).

\section{Discussion}

The single channel thread, straight course with abrupt bends, confinement within steep banks and coincidence with the Whiteclay Fault Zone all strongly point towards a structural control on the WGB fluvial system. The orientation and location of the channel system southeast of the Black Hills Dome of South Dakota suggest that it formed via reactivation of Black Hills uplift stresses in Early Miocene times. The character of the channel belt fill indicates that the formative channel was a moderatesized stream that wandered to a limited degree across a narrow belt 100-300 m wide, and was competent to carry sediment up to coarse gravel grade in mainly clear water flows. All this is suggestive of a robust discharge regime including substantial peak flows on a regular basis. This is out of context within the Ogallala Group as a whole, which preserves extensive low-gradient, large meandering river systems (Runningwater and Valentine Formations, Figure 2). Although it is possible that other, as yet undiscovered gravelly channel fills are preserved within the Ogallala Group of western Nebraska, it is nonetheless clear that the WGB are anomalous in indicating such an energetic flow regime. The WGB is interpreted as recording an otherwise unknown pluvial period within the Lower Miocene that is associated with a previously unrecognized fossil mammal assemblage, presumably attracted into the area by the reliable supply of water and food. The fauna, which includes a large variety of probable reworked material, is nonetheless distinctive because of the occurrences of two new taxa, a primitive species of the oreodont Brachycrus and a mery- 
chippine horse. These, together with merycodonts, suggest correlation with the Hemmingfordian North American Land Mammal Age, and allow an age estimate of 17-17.5 Ma for the WGB (Tedford et al., 2004).

At the Gordon Pit 1, at least two cycles of channel fill gravel (Facies 3 ) overlain by cross-bedded sand (Facies 4) are evident (possibly three: Figure 8), suggesting some repetitive process of channel establishment and partial to complete infilling. These crude fining upward cycles could potentially be climatically-driven oscillations, with initial channel incision caused by an increase in annual precipitation, runoff and consequent vertical erosion, gravel deposition reflecting a period of abundant coarse sediment supply from channel widening and bank collapse, and subsequent sand deposition during the latter stages of channel filling. The final stage in the filling of the WGB channel belt is the formation and pedogenic modification of silts and fine-grained sands, perhaps reflecting a return to the more semi-arid climate regarded as characteristic of the Lower Miocene in this region.

There has been considerable interest in the characteristics of alluvial channel bodies in structurally controlled settings (e.g., Schumm et al., 2002). Modeling studies have been carried out to attempt to simulate alluvial stacking patterns in two and three dimensions (Allen, 1978, 1979; Leeder, 1978; Bridge and Leeder, 1979; Bridge and Mackey, 1993). Documented examples of modern structurally-controlled drainage include rivers confined by grabens and half-grabens, and narrower, straight, single thread channels along fault trends (e.g., Alexander and Leeder, 1987, 1990; Peakall, 1998; Peakall et al., 2000; Schumm et al., 2002). Cases from the rock record that have been interpreted as structurally controlled drainage rely generally on indirect evidence, such as the stacking patterns predicted by modeling studies together with some facies indicators (e.g., Fielding, 1984; Alexander, 1986; Fielding and Johnson, 1987; Leeder et al., 1996). The value of the WGB case is that it is an ancient example of a clearly structurally controlled fluvial system that is fully exposed at the surface, allowing it to be mapped in three dimensions. The WGB system is unlike most described examples, being evidently facilitated by linear fault rupture topography, rather than by ground tilting effects (e.g., Peakall et al., 2000; Schumm et al., 2002).

\section{Conclusions}

The newly recognized Whiteclay Gravel Beds (WGB) of the Ogallala Group in northwest Nebraska, USA, constitute a previously unknown window into climate and tectonic activity in the Lower Miocene of the High Plains of central-western North America. The WGB were deposited in a narrow (100-300 m wide), linear tract bounded by steep-sided walls and inset into older Cenozoic strata, that can be traced over at least $30 \mathrm{~km}$ at the present land surface as a single channel belt. This belt has a distinctive planform, with long straight reaches ending in abrupt corners, and is coincident at least in part with the Whiteclay Fault zone. The channel is therefore interpreted to have followed fault rupture topography that propagated in an eastsoutheastward direction away from the Black Hills Dome of South Dakota at about 17.5 Ma. This is some considerable time after the generally-regarded date of uplift of the Black Hills Dome, and indicates a degree of tectonic rejuvenation in the region.

The WGB comprise a composite gravel-dominated, incised valley fill up to $20 \mathrm{~m}$ thick, confined within steep walls. Five facies were recognized, and interpreted as a variety of mainly low-amplitude gravel and sand sheets in channel floor environments. Component channels were 20-50 m wide and 2-4 m deep, and probably braided across the narrow channel belt. Gravel channel fills and sheets are typically overlain by well-sorted sand bodies, and this vertical succession is repeated in some exposures, implying a repetitive pattern of multiple channel incision and infilling over time, perhaps related to cyclical variations in runoff or to pulses of tectonic activity.

The diverse vertebrate fauna found in the Gordon pits includes local first occurrences of merychippine horses, merycodonts, and the oreodont Brachycrus, and indicates the WGB were deposited near the boundary between the early and late Hemingfordian North American Land Mammal Age, c. 17.5 Ma (Tedford et al., 2004), suggesting movement along the Whiteclay Fault Zone at this time. The unit provides a window into a pluvial period in the Early Miocene that is unrecorded elsewhere in the region.

Acknowledgments - We thank the staff of the Nebraska National Forest for support, cooperation, and the use of office facilities during this research. Field work was funded in part by the University of Nebraska State Museum (UNSM) Highway Salvage Paleontology Program, the Nebraska National Forest from 1991-1995, and the University of Nebraska-Lincoln Conservation and Survey Division STATEMAP projects for 19962005. This work was conducted under Special-Use Permits from the Nebraska National Forest to Bruce E. Bailey of the University of Nebraska State Museum (User 
No. 1044-1), Hannan E. LaGarry (User No. 2033-4), and Leigh Anne LaGarry (User No. 2033-6) of the University of Nebraska-Lincoln Conservation and Survey Division. M. R. Voorhies is thanked for confirming the biochronologic age determination. R. Hillier and J. Holbrook are thanked for constructive reviews of the submitted manuscript.

\section{References}

Alexander, 1986 - J. Alexander, Idealised flow models to predict alluvial sandstone body distribution in the middle Jurassic Yorkshire Basin, Mar. Pet. Geol. 3 (1986), pp. 298-305.

Alexander and Leeder, 1987 - J. Alexander and M. R. Leeder, Active tectonic control of alluvial architecture. In: F. G. Ethridge, R. M. Flores, and M. D. Harvey, eds., Recent Developments in Fluvial Sedimentology, Spec. Publ. Soc. Econ. Paleont. Miner. vol. 39 (1987), pp. 243-252.

Alexander and Leeder, $1990 \bullet \mathrm{J}$. Alexander and M. R. Leeder, Geomorphology and surface tilting in an active extensional basin, SW Montana, USA, J. Geol. Soc. (Lond.) 147 (1990), pp. 461-467.

Allen, 1978 - J. R. L. Allen, Studies in fluviatile sedimentation: an exploratory quantitative model for architecture of avulsion-controlled alluvial suites, Sediment. Geol. 21 (1978), pp. 129-147.

Allen, 1979 • J. R. L. Allen, Studies in fluviatile sedimentation: an elementary geometrical model for the connectedness of avulsion-related channel sand bodies, Sediment. Geol. 24 (1979), pp. 253-267.

Bailey, 2001 • Bailey, B. E., 2001. Miocene stratigraphy of the Niobrara River valley, Western Cherry County, Nebraska. Unpublished MS thesis, University of Nebraska, Lincoln, 92p.

Blodgett and Stanley, $1980 \cdot$ R. H. Blodgett and K. O. Stanley, Stratification, bedforms and discharge relations of the Platte River system, Nebraska, J. Sediment. Petrol. 50 (1980), pp. 139-148.

Bluck, 1974 - B. J. Bluck, Structure and directional properties of some valley sandur deposits in southern Iceland, Sedimentology 21 (1974), pp. 533-544.

Bluck, 1979 - B. J. Bluck, Structure of coarse grained braided stream alluvium, Trans. R. Soc. Edinb. 70 (1979), pp. 181-221.

Brayshaw, 1984 - A. C. Brayshaw, Characteristics and origin of cluster bedforms in coarse-grained alluvial channels. In: E. H. Koster and R. Steel, eds., Sedimentology of Gravels and Conglomerates, Can. Soc. Petrol. Geol. Mem. vol. 10 (1984), pp. 77-85.

Bridge, 2003 - J. S. Bridge, Rivers and Floodplains: Forms, Processes and Sedimentary Record, Blackwell Science, Oxford (2003) 491 pp.
Bridge and Leeder, 1979 - J. S. Bridge and M. R. Leeder, A simulation model of alluvial stratigraphy, Sedimentology 26 (1979), pp. 617-644.

Bridge and Mackey, 1993 - J. S. Bridge and S. D. Mackey, A revised alluvial stratigraphy model. In: M. Marzo and C. Puigdefabregas, eds., Alluvial Sedimentation, Spec. Publ. Int. Ass. Sediment. vol. 17 (1993), pp. 319-337.

Bridge et al., 1986 • J. S. Bridge, N. D. Smith, F. Trent, S. L. Gabel, and P. Bernstein, Sedimentology and morphology of a low-sinuosity river: Calamus River, Nebraska Sand Hills, Sedimentology 33 (1986), pp. 851-870.

Church and Gilbert, 1975 • M. Church and R. Gilbert, Proglacial fluvial and lacustrine environments. In: A. V. Jopling and B. C. MacDonald, eds., Glaciofluvial and Glaciolacustrine Sedimentation, Spec. Publ. Soc. Econ. Paleont. Miner. vol. 23 (1975), pp. 22-100.

Cook, 1965 - H. J. Cook, Runningwater Formation, middle Miocene of Nebraska, Am. Mus. Novit. 2227 (1965), pp. 1-8.

Clark, 1975 - J. Clark, Controls of sedimentation and provenance of sediments in the Oligocene of the central Rocky Mountains. In: B. F. Curtis, ed., Cenozoic history of the southern Rocky Mountains, Geol. Soc. Am. Mem. vol. 144 (1975), pp. 95-117.

Fielding, 1984 - C. R. Fielding, A coal depositional model for the Durham Coal Measures of NE England, J. Geol. Soc. (Lond.) 141 (1984), pp. 919-931.

Fielding, in press - Fielding, C. R., in press. Sedimentology and stratigraphy of large river deposits: recognition in the ancient record, and distinction from "incised valley fills". In: Gupta, A. (ed.), Large Rivers: Geomorphology and Management. Wiley Interscience, Chichester.

Fielding and Gibling, 2005 - C. R. Fielding and M. R. Gibling, Distinguishing between channel and valley fills: definitions, diagnostic criteria and dimensional data, 8th Int. Conf. on Fluvial Sedimentology, Delft, August 7-12, 2005 (2005), p. 101 (Abstract volume).

Fielding and Johnson, 1987 • C. R. Fielding and G. A. L. Johnson, Sedimentary structures associated with extensional fault movement from the Westphalian of NE England. In: M. P. Coward, J. F. Dewey and P. L. Hancock, eds., Continental Extensional Tectonics, Geol. Soc. Spec. Publ. vol. 28 (1987), pp. 511-516.

Hein and Walker, 1977 • F. J. Hein and R. G. Walker, Bar evolution and development of stratification in the gravelly, braided, Kicking Horse River, British Columbia, Can. J. Earth Sci. 14 (1977), pp. 562-570.

Heller et al., 1988 • P. L. Heller, C. L. Angevine, N. S. Winslow, and C. Paola, Two-phase model of foreland-basin sequences, Geology 16 (1988), pp. 501-504.

Holbrook, 2001 - J. Holbrook, Origin, genetic relationships, and stratigraphy over the continuum of fluvial channelform bounding surfaces: an illustration from middle Cretaceous strata, southeastern Colorado, Sediment. Geol. 144 (2001), pp. 179-222. 
Hunt, 2002 - R. M. Hunt, New amphicyonid carnivorans (Mammalia, Daphoeninae) from the Early Miocene of southeastern Wyoming, Am. Mus. Novit. 3385 (2002).

Leeder, 1978 - M. R. Leeder, A quantitative stratigraphic model for alluvium with special reference to channel deposit density and interconnectedness. In: A. D. Miall, ed., Fluvial Sedimentology, Can. Soc. Petrol. Geol. Mem. vol. 5 (1978), pp. 587-596.

Leeder et al., 1996 - M. R. Leeder, G. H. Mack, J. Peakall, and S. L. Salyards, First quantitative test of alluvial stratigraphic models: Southern Rio Grande rift, New Mexico, Geology 24 (1996), pp. 87-90.

Lisenbee and DeWitt, 1993 - A. L. Lisenbee and E. DeWitt, Laramide evolution of the Black Hills Uplift. In: A. W. Snoke, J. R. Steidtmann, and S. M. Roberts, eds., Geology of Wyoming, Geol. Surv. Wyoming Mem. vol. 5 (1993), pp. 374-412.

Lunt and Bridge, $2005 \bullet$ I. A. Lunt and J. S. Bridge, Formation and preservation of open-framework gravel strata, 8 th International Conference on Fluvial Sedimentology, Delft, August 7-12, 2005, Abstracts Volume, Delft University of Technology (2005), p. 180.

Lunt et al., 2004 - I. A. Lunt, J. S. Bridge, and R. S. Tye, A quantitative, three-dimensional depositional model of gravelly braided rivers, Sedimentology 51 (2004), pp. 377-414.

Miall, 1985 - A. D. Miall, Architectural-element analysis: a new method of facies analysis applied to fluvial deposits, Earth-Sci. Rev. 22 (1985), pp. 261-308.

Peakall, 1998 - J. Peakall, Axial river evolution in response to half-graben faulting: Carson River, Nevada, J. Sediment. Res. 68 (1998), pp. 788-799.

Peakall et al., 2000 - J. Peakall, M. R. Leeder, J. L. Best, and P. Ashworth, River response to lateral ground tilting: a synthesis and some implications for the modeling of alluvial architecture in extensional basins, Basin Res. 12 (2000), pp. 413-424.

Retallack, 1983 - G. J. Retallack, Late Eocene and Oligocene paleosols from Badlands National Park, South Dakota, Geol. Soc. Am. Spec. Pap. 193 (1983) (82 p).

Rust, 1975 - B. R. Rust, Fabric and structure in glaciofluvial gravels. In: A. V. Jopling and B. C. MacDonald, eds., Glaciofluvial and Glaciolacustrine Sedimentation, Spec. Publ. Soc. Econ. Paleont. Miner. vol. 23 (1975), pp. 238-248.

Schumm et al., 2002 - S. A. Schumm, J. F. Dumont, and J. M. Holbrook, Active Tectonics and Alluvial Rivers, Cambridge University Press, Cambridge (2002) 276 pp. .

Siegenthaler and Huggenberger, 1993 - C. Siegenthaler and P. Huggenberger, Pleistocene Rhine gravel: deposits of a braided river system with dominant pool preservation. In: J. L. Best and C. L. Bristow, eds., Braided Rivers, Geol. Soc. Spec. Publ. vol. 75 (1993), pp. 147-162.

Skinner and Johnson, 1984 • M. F. Skinner and F. W. Johnson, Tertiary stratigraphy and the Frick collection of fossil vertebrates from north-central Nebraska, Bull. Am. Mus. Nat. Hist. 78 (1984), pp. 215-368.

Smith, 1971 - N. D. Smith, Transverse bars and braiding in the lower Platte River, Nebraska, Geol. Soc. Amer. Bull. 82 (1971), pp. 3407-3420.

Smith, 1974 - N. D. Smith, Sedimentology and bar formation in the upper Kicking Horse River, a braided outwash stream, J. Geol. 82 (1974), pp. 205-223.

Souders, $1981 \bullet$ V. L. Souders, Geology and groundwater supplies of southern Dawes and northern Sheridan Counties, Nebraska, Nebraska Conservation and Survey Division, IANR Open File Report vol. 29, University of Nebraska, Lincoln (1981) 125 p. .

Stanley and Benson, 1979 - K. O. Stanley and L. V. Benson, Early diagenesis of High Plains Tertiary vitric and arkosic sandstone, Wyoming and Nebraska. In: P. A. Scholle and P. R. Schluger, eds., Aspects of Diagenesis, Soc. Econ. Paleont. Miner. Spec. Publ. vol. 26 (1979), pp. 401-423.

Swinehart et al., 1985 - J. B. Swinehart, V. L. Souders, H. M. DeGraw, and R. F. Diffendal Jr., Cenozoic paleogeography of western Nebraska. In: R. M. Flores and S. S. Kaplan, eds., Rocky Mountain Section, Soc. Econ. Paleont. Miner., Cenozoic Paleogeography of west-central United States: Rocky Mountain Paleogeography Symposium vol. 3 (1985), pp. 209-229.

Tedford et al., 2004 - R. H. Tedford, L. B. Albright III, A. D. Barnosky, I. Ferrusquia-Villafranca, R. M. Hunt, Jr., J. E. Storer, C. C. Swisher III, M. R. Voorhies, S. D. Webb, and D. P. Whistler, Mammalian biochronology of the Arikareean through Hemphillian interval (late Oligocene through early Pliocene epochs). In: M. O. Woodburne, ed., Late Cretaceous and Cenozoic mammals of North America, Columbia University Press (2004), pp. 169-231.

Terry, 1998 - D. O. Terry, Lithostratigraphic revision and correlation of the lower part of the White River Group. In: D. O. Terry, H. E. LaGarry and R. M. Hunt, eds., Depositional environments, lithostratigraphy, and biostratigraphy of the White River and Arikaree Groups (late Eocene to Early Miocene, North America), Geol. Soc. Am. Spec. Pap. vol. 325 (1998), pp. 14-38.

Zingg, 1935 • T. Zingg, Beitrag zür Schotteranalyse, Schweiz. Mineral. Petrogr. Mitt. Bd. 15 (1935), pp. 39-140. 